\title{
EFEK GENDER DAN TIPE KEPRIBADIAN DALAM PROSES PEMEROLEHAN BAHASA JAWA SEBAGAI BAHASA KEDUA
}

\author{
Paundra Pristyasiwi \\ Universitas Negeri Surabaya \\ paundrapristyasiwi16070835076@mhs.unes.ac.id
}

\section{ABSTRAK}

\section{ABSTRACT}

Pemerolehan bahasa kedua tidak lepas dari beberapa faktor pendukung dan faktor penghambat. Salah satu faktor yang berpengaruh dalam keberhasilan proses pemerolehan bahasa kedua adalah usia, jenis kelamin dan tentunya perbedaan kepribadian setiap individu. Tujuan dari penelitian ini adalah untuk mendiskripsikan efek gender dan tipe kepribadian terhadap pemerolehan bahas Jawa sebagai bahasa kedua pada siswa di SMK Giki 1 Surabaya. Penelitian ini dilakukan pada siswa kelas sebelas dan duabelas yang berasal dari luar Jawa (Surabaya) tahun akademik 2017/2018. Metode penelitian yang digunakan adalah metode deskriptif kualitatif dengan model analisis kategoris deskriptif. Hasil penelitian ini membuktikan bahwa (1) terdapat perbedaan pada proses pemerolehan bahasa kedua atara siswa perempuan dan laki-laki, siswa perempuan memiliki kemauan dan kemampuan yang lebih tinggi daripada siswa laki-laki, (2) terdapat perbedaan penguasaan pemerolehan bahasa pada siswa berkepribadian ekstrovert dan introvert, siswa ektrovert memiliki kompetensi pemerolehan lebih tinggi daripada siswa berkepribadian introvert.

Kata Kunci: gender, tipe kepribadian, pemerolehan bahasa

The process of acquiring a second language can not be separated from several supporting factors and factors of learning. One of the factors that influence the success of the second language acquisition process is age, gender and of course individual personality differences. The purpose of this study is to describe the effect of gender and personality type on the acquisition of Java as the second language of students in SMK Giki 1 Surabaya. This research was conducted on eleven and twelve grade students from outside Java (Surabaya) academic year 2017/2018. The research method used is descriptive qualitative method with descriptive categorical analysis model. The results of this study prove that (1) there is a difference in the process of obtaining a second language among female students and men, female students have higher willingness and ability than male students, (2) there is difference of acquisition of language acquisition in extrovert person and introverts, orthograd students have higher acquisition competencies than introverted personality students.

Keywords: gender, personality type, language acquisition 
Proses pemerolehan bahasa menjadi salah satu diskursus yang menarik untuk didiskusikan. Proses pembelajaran dan pemerolehan bahasa tidak lepas dari berbagai macam faktor pendukung dan faktor penghambat. Hal ini juga dikemukakan oleh Ardiana dan Sodiq (2008:4.21) bahwa terdapat dua faktor yang mampu mempengaruhi proses pemerolehan bahasa. Pertama, faktor internal yang mencakup perkembangan kognisi dan IQ. Kedua, faktor ekternal yang berasal dari lingkungan sosial. Bisa dikatakan bahwa faktor tersebut dapat berasal dari pebelajar sendiri (internal factor) dan dari luar pebelajar (external factor). Dari dalam diri pebelajar, faktor-faktor internal tersebut dapat berupa gender, motivasi, minat, sikap, kepribadian, gaya belajar, sedangkan faktor luar dapat berupa tuntutan dari orang tua, faktor sekolah (guru, teman), dan lingkungan sekitar.

Di antara beberapa faktor tersebut, peneliti memfokuskan penelitian ini pada faktor internal, khususnya gender dan kepribadian. Hal ini menarik untuk dikaji karena gender dan kepribadian menjadi faktor penentu keberhasilan seseorang untuk belajar bahasa. Gender dipilih berdasarkan pengamatan sebelumnya yang sudah dilakukan. Peneliti melihat bahwa kebanyakan siswa laki-laki cenderung lebih sedikit berbicara daripada siswa perempuan. Sedangkan, kepribadian dipilih untuk melihat dan membedakan keberhasilan pebelajar dengan sifat terbuka dan tertutup. Gender merupakan aspek psikososial dari kelaki-lakian (kejantanan) dan keperempuanan (kewanitaan). Perbedaan gender dianggap sebagai salah satu faktor yang dapat mempengaruhi prestasi belajar. Begitu juga dalam interaksi sosial, gender merupakan salah satu unsur konteks yang ada dalam pertuturan. Elliott, dkk dalam (Ratminingsih, 2013) menegaskan terdapat beberapa perbedaan gender yang ditunjukkan dari beberapa karakteristik.

Dari segi kemampuan verbal, dijelaskan bahwa perempuan lebih baik dalam berbagai tugas-tugas verbal sejak awal perkembangannya, dan menjadi superioritasnya yang terpelihara. Chaer (2015:133) menyatakan bahwa dalam beberapa hal otak wanita lebih unggul dari otak pria. Dikatakan bahwa otak wanita lebih seimbang, hal ini terlihat dengan responsifnya seorang wanita. Selain itu wanita juga lebih awet dan selektif. Ini menjadi bukti bahwa wanita sering menderita depresi daripada pria. Sedangkan pria memiliki lebih banyak masalah berbahasa daripada perempuan. Chaer (2015:136) menjelaskan bahwa otak pria lebih cepat menyusut daripada otak wanita dilihat dari semakin bertambahnya usia. Penyusutan tersebut berkaitan degan efisiensi pemakaian energi. Otak wanita mampu untuk menyesuaikan kecepatan metabolisme otak, sedangkan pria tidak.

Selain faktor gender, faktor kepribadian (personality), juga berpengaruh terhadap perkembangan seseorang untuk belajar bahasa. Adanya kepribadian yang berbeda mampu mempengaruhi gaya hidup seseorang serta nilai-nilai yang berkembang secara 
teratur sehingga tingkah laku menjadi lebih konsisten dan mudah di perhatikan. Adanya kepribadian tersebut sangat mempengaruhi proses interaksi dan komunikasi antar individu. Dalam proses pemerolehan bahasa kedua terdapat faktor dan strategi dalam pemerolehan dan penguasaannya. Pemerolehan bahasa kedua juga dipengaruhi oleh proses sadar mental dan alam bawah sadar. Namun, proses mental ini dipengaruhi oleh berbagai faktor individu yang mungkin mempercepat, memperlambat atau bahkan bisa menghentikan proses perolehan bahasa.

Kumaravadivelu (dalam Ratminingsih, 2013) menegaskan ada beberapa faktor individual yang berpengaruh terhadap perkembangan bahasa kedua (L2) yaitu umur, kecemasan, empati, ekstroversi, introversi, dan pengambilan resiko. Di antara faktorfaktor kepribadian yang disebutkan di atas, peneliti memfokuskan pada ekstroversi dan introversi dalam penelitian ini. Seseorang dapat menjadi ekstrovert atau introvert, tergantung dengan arah aktivitas mereka. Ekstrovert adalah orang yang berpikir mengenai hal-hal secara objektif dan luas, sedangkan introver lebih berpikir ke arah subjektif atau dirinya sendiri. Ekstroversi juga bisa dikatakan seseorang yang bersifat sosialisasi, senang berbicara, hidup, dan aktif. Orang ekstrovert tidak selalu bermulut besar dan suka bicara. Ada juga orang ekstrovert yang pendiam tetapi masih membutuhkan bantuan orang lain. Sedangkan introvert bersifat, non-sosial, dan merasa bisa memenuhi kebutuhannya tanpa refleksi dari orang lain.

Yulianto, (107:2011) menjelaskan bahwa seorang pebelajar memiliki sifat terbuka dan tertutup. Pebelajar yang memeiliki sifat terbuka cenderung lebih mudah berinteraksi menggunakan bahasa kedua. Begitu juga saat didalam kelas, pebelajar yang memiliki sifat terbuka ini memiliki tingkat keberhasilan yang lebih tinggi dalam pembelajaran. Sebaliknya siswa dengan kepribadian atau sifat yang tertutup cenderung mengalami kesulitan dalam berinteraksi maupun belajar di dalam kelas. Pebelajar dengan kepribadian tertutup merasa segan untuk berkomunikasi dan enggan menerima kritikan.

Oleh sebab itu, tipe-tipe kepribadian pada pebelajar ini perlu diketahui oleh setiap guru. Untuk menyukseskan pembelajaran, terutama bahasa, setiap guru harus mampu mencermati dan menyikapi pebelajar yang memiliki sifat tertutup. Karena sifat tersebut mampu menghambat proses pembelajaran bahasa. Pebelajar yang introvert lebih tertarik untuk berinteraksi jika suasana yang diciptakan dalam kelas lebih menyenangkan. Dengan demikian, sebaiknya para pemelajar harus menciptakan suasana yang menyenangkan saat dikelas. Untuk mengatasi tipe-tipe pebelajar introvert atau tertutup.

Tujuan dari penelitian ini adalah untuk mendeskripsikan efek gender dan tipe kepribadian terhadap pemerolehan bahas Jawa sebagai bahasa kedua pada siswa SMK Giki 1 Surabaya. SMK Giki adalah salah satu sekolah swasta di Surabaya, sekolah kejuruan ini merupakan tempat dimana peneliti menjadi tenaga pengajar. 
Penelitian ini dilakukan pada siswa kelas XI dan XII yang berasal dari luar Jawa (Surabaya). Peneliti tidak mengabil banyak sampel melainkan hanya mengambil lima siswa yang berasal dari luar Jawa (Surabaya), karena memang terbatas sekali siswa yang berasal dari luar Jawa.

Pemerolehan bahasa kedua disini yang dimaksud adalah bahasa Jawa. Bahasa Jawa dipilih karena kajian pemerolehan bahasa Jawa sebagai bahasa kedua belum banyak dilakukan. Padahal pengguna bahasa Jawa hampir tersebar diseluruh Indonesia. Bahasa Jawa yang menjadi bahasan ini adalah bahasa Jawa standar yang dipergunakan dalam kehidupan sehari-hari. Berdasarkan ragam sosialnya bahasa Jawa yang digunakan dalam bahasan ini adalah bahasa Jawa ragam ngoko. Menurut Adipitoyo (2013:4) ragam ngoko dalam bahasa Jawa merupakan ragam pokok atau primer. Hal tersebut diperoleh berdasarkan perbandingan antara bentukbentu leksikal ngoko dan krama. Berdasarkan perbandinganya tampak, bahwa tidak ada bentuk leksikal ragam krama yang tidak ada ragam ngokonya.

Oleh sebab itu mengambil siswa yang berasal dari luar Jawa dan sudah menetap di Surabaya cukup lama. Hal ini dilakukan untuk mengetahui seberapa lancar mereka bisa berinteraksi menggunakan bahasa kedua. Bahasa Jawa dipilih sebagai bahasa kedua karena bahasa pertama yang mereka peroleh adalah bahasa Indonesia dan bahasa daerah (bukan Jawa). Karena meraka bertempat tinggal di Surabaya yang mayoritas masyarakatnya menggunakan bahasa Jawa, sedikit banyak mereka harus mampu berkomunikasi menggunakan bahasa Jawa. Hal ini dilakukan untuk menghindari kesalah pahaman antar individu saat berinteraksi.

Pebelajar bahasa kedua di sini berasal dari Bandung, Kalimantan, Lombok, NTT, dan Jakarta. Begitu juga lama mereka tinggal di Surabaya berbeda-beda, ada yang masih dua tahun, bahkan ada yang sudah enam tahun. Hal tersebut diketahui dari wawancara secara mendalam terhadap pebelajar. Maka dari itu peneliti tertarik utuk menginvestigasi dan membedakan pemerolehan bahasa pada setiap pebelajar tersebut.

Penelitian ini dapat bermanfaat bagi teman-teman guru khususnya guru bahasa. Lebih baik jika melihat tipe-tipe pebelajarnya terlebih dahulu sebelum melanjutkan proses pembelajaran. Untuk menentukan strategi dan metode pembelajaran yang cocok pada saat mengahadapi pebelajar dengan tipe kepribadian introvert. Guna mencapai keberhasilan yang sama antara pebelajar introvert dan ekstrovert dalam penguasaan bahasa.

METODE

Penelitian ini menggunakan pendekatan kualitatif berjenis deskriptif. Dalam hal ini peneliti melakukan pengamatan terhadap fenomena pembelajaran bahasa Jawa sebagai bahasa kedua di SMK Giki 1 Surabaya. Sumber data penelitian ini adalah siswa kelas XI dan XII SMK Giki 1 Surabaya yang berasal dari luar Jawa (Surabaya). 
Tabel 1. Klasifikasi Pebelajar Bahasa

\begin{tabular}{|c|c|c|c|c|c|}
\hline No & Kode & JK & Usia & Asal Daerah & Di SBY \\
\hline 1 & Eg/11/MM & $\operatorname{Pr}$ & 16 & Jakarta & $3 \mathrm{Th}$ \\
\hline 2 & $\mathrm{Ib} / 12 / \mathrm{MM}$ & $\mathrm{Lk}$ & 17 & Bandung & $3 \mathrm{Th}$ \\
\hline 3 & $\mathrm{Rs} / 12 / \mathrm{MM}$ & $\mathrm{Pr}$ & 17 & Kalimantan & $2 \mathrm{Th}$ \\
\hline 4 & $\mathrm{Rv} / 11 / \mathrm{MM}$ & $\mathrm{Lk}$ & 16 & Maluku & $6 \mathrm{Th}$ \\
\hline 5 & $\mathrm{Sy} / 12 / \mathrm{MM}$ & $\mathrm{Pr}$ & 17 & Lombok & $6 \mathrm{Th}$ \\
\hline
\end{tabular}

Keterangan:

$\mathrm{JK}=$ jenis kelamin

$\operatorname{Pr}=$ perempuan

Lk = laki-laki

Ektv $=$ ekstrovert

Intv = introvert

SBY = Surabaya

Tabel di atas merupakan klasifikasi data yang diperoleh dari hasil wawancara secara mendalam dengan pebelajar bahasa. Tabel di atas diklasifikasikan berdasarkan asal daerah dari luar Jawa (Surabaya). Lima siswa ini dipilih karena hanya meraka yang berasal dari luar Jawa (Surabaya). Dapat dilihat dari mana meraka berasal dan sudah berapa lama tinggal di Surabaya, hal tersebut juga mempengaruhi penguasaan bahasa Jawa.

Pengumpulan data dalam penelitian ini menggunakan metode observasi langsung, catat, dan wawancara. Metode observasi langsung dilkukan oleh peneliti, hal ini dilakukan karena penliti perlu melihat langsung perkembangan pebelajar bahasa tersebut. Kemudian metode catat, metode ini dilakukan dengan cara mencatat apapun yang diujarkan oleh anak dalam suatu buku harian. Yang terakhir adalah metode wawancara, metode ini berguna untuk mengecek ulang sesuatu yang ingin diketahui oleh peneliti.

Dalam penelitian ini digunakan tiga instrumen penelitian: (1) pedoman tes pengamatan berbicara, instrumen ini untuk menguji seberapa lancar mereka berbicara bahasa Jawa, (2) pedoman wawancara, instrumen ini untuk mengetahui hal-hal yang mendalam dari pebelajar bahasa, dan (3) angket yang disusun secara konseptual, angket tersebut berguna untuk mengetahui jenis kepribadian seseorang.

Setelah data terkumpul, kemudian dianalisis menggunakan metode kategoris dan dheskriptif. Metode kategoris adalah metode analisis data berdasarkan bagian-bagian yang sudah diklasifikasikan. Sedangakan metode deskriptif adalah metode analisis data yang penjelasanya berdasarkan gambaran atau hakikat dari data tersebut.

PEMBAHASAN

Hasil penelitian ini dideskripsikan dalam sebuah tabel. Tabel tersebut memperlihatkan klasifikasi gender dan keperibadian pebelajar, serta memperlihatkan kemampuan berbicara siswa berdasarkan gender dan kepribadian. Sebelum mengetahui tipe 
kepribadian dan penguasaan bahasa, alangkah baiknya jika mengetahui latar belakang dari masing-masing pebelajar.

Dari hasil wawancara dan pengamatan kode Ib/12/MM (17) dengan jenis kelamin laki-laki yang berasal dari Bandung. Pada tahun pertama berada di Surabaya sangat kesulitan saat berkomunikasi dengan teman sebayanya. Hal itu menyebabkan Iqbal kesulitan untuk mendapat teman. Karena teman-temanya memakai bahasa Jawa dan jarang memakai bahasa Indonesia. Karena Ib/12/MM adalah seorang laki-laki yang aktif berinteraksi, dalam waktu dua tahun sudah mulai mampu untuk berbahasa Jawa, setelah 3 tahun sudah fasih berbahasa Jawa walaupun logat sundanya masih terlihat. Hal ini terbukti saat Ib/12/MM berkomunikasi dengan peneliti.

Sama-sama sudah tiga tahun di Surabaya pebelajar Eg/11/MM (16) berasal dari Jakarta, penguasaan bahasa Jawanya sangat berbeda jauh dengan Ib/12/MM (17). Eg/11/MM diketahui siswa yang tertutup dan jarang berkomunikasi. Hal ini yang menyebabkan Eg/11/MM menjadi sulit untuk berkomunikasi menggunakan bahasa Jawa. Selain itu keluarga diketahui juga tidak membiasakan untuk berbahasa Jawa.

Berbeda dengan pebelajar (3), Rs/12/MM (17) yang beraal dari Kalimatan. Pebelajar ini diketahui sebagai pebelajar yang paling baru berada di Jawa (Surabaya). Dapat dilihat pada tabel bahwa Rs/12/MM masih 2 tahun berada di Surabaya. Namun hal tersebut tidak membuat Risma menjadi pebelajar yang paling tidak bisa berbahasa Jawa. Melalui wawancara dan pengamatan, peneliti mendapat jawaban bahwa Rs/12/MM ini mempunyai kemauan tinggi untuk belajar bahasa Jawa, karena semua teman dan keluarganya menggunakan bahawa Jawa.

Dapat dilihat dari tabel dalam bab metode, bahwa pebelajar yang bisa dikatakan sudah fasih dan sangat menguasai bahasa Jawa. Tentunya siswa (4) dan (5), karena sudah telihat lamanya mereka tinggal di Surabaya. Waktu enam tahun bukan waktu yang singkat untuk mempelajari sebuah bahasa.

Dari hasil wawancara dengan Rv/11/MM yang sudah cukup lama berada di Surabaya mengaku bahwa mempelajari bahas Jawa tidak terlalu sulit. Bahasa Jawa yang dimaksud oleh Rv/11/MM adalah bahasa Jawa standar tanpa memperhatikan tingkat tuturnya. Setelah diajukan pertanyaan menggunkan bahasa Jawa krama $\mathrm{Rv} / 11 / \mathrm{MM}$ bisa menjawab walau yang ia tuturkan tidak sesuai dengan tingkat tutur bahasa Jawa.

Tingkat tutur bahasa Jawa memang sulit untuk dipelajari, karena banyak sekali penggunaan kata yang berbeda dari bahasa Jawa standar. Penutur aslinya saja tidak jarang kesulitan saat berbicara menggunkaan bahasa Jawa dengan tingkatan krama tersebut. Pristyasiwi (2017: 40) mengatakan bahwa kesulitan berbahasa Jawa berasal dari kerumitan yang terdapat dalam tingkat tutur tersebut. Selain itu karena kurang terbiasa menggunkaannya dalam kegiatan sehari-hari sehingga menjadi terasa sulit. Oleh 
sebab itu dari lingkungan keluarga harus ikut membiasakan mereka untuk selalu menggunakan bahasa Jawa.

\section{Identifikasi Gender}

Bagian ini akan mendeskripsikan hasil tes berbicara menggunakan bahasa kedua (Jawa). Hasil tes tersebut membuktikan bahwa pebelajar dengan jenis kelamin laki-laki lebih rendah nilainya. Sedangkan siswa berjenis kelamin perempuan memiliki nilai yang cukup tinggi. Hal ini sesuai dengan ungkapan Grey (2001) bahwa perempuan memiliki kecerdasan verbal (bahasa) yang lebih tinggi dibandingkan dengan laki-laki. Bahkan kecerdasan verbal pada perempuan sudah ada sejak lahir.

Selain hasil tes berbicara menggunakan bahasa Jawa, bagian ini juga medeskripsikan perbedaan pemerolehan bahasa pada lakilaki dan perempuan. Secara umum laki-laki dan perempuan memiliki perbedaan dalam pemerolehan bahasa. Bisa saja yang diperoleh laki-laki tidak diperoleh perempuan. Bisa juga sama-sama memperoleh tetapi hanya diujarkan laki-laki tidak diujarkan oleh perempuan atau sebaliknya.

Hal ini disebabkan oleh faktor emosional dan intelektual antara laki-laki dan perempuan yang memiliki perbedaan. Seperti halnya saat ingin mengucapkan sesuatu hal yang agak memalukan, lakilaki akan berterus terang sedangkan perempuan tidak akan berterus terang. Begitu juga saat bertengkar atau beradu argumen. Laki-laki akan berusaha untuk menyembunyikan emosinya, sedangkan perempuan sebaliknya. Inilah yang menyebabkan perbedaan dalam pemerolehan bahasa laki-laki dan perempuan.

Penilaian diambil dari kelancaran mereka dalam berbahasa Jawa, dengan memperhatikan penggunaan kata yang tepat, dan pelafalan kata. Dalam bahasa Jawa penggunaan kata menjadi salah satu hal penting, jika tidak mengetahui penggunaan kata yang benar bisa menyimpang dari tingkat tutur bahasa Jawa. Begitu juga dengan pelafalan kata, dalam bahasa Jawa kata 'tembung' yang ditulis tidak sama dengan yang diucapkan. Oleh sebab itu hal ini juga menjadi salah alat ukur untuk menguji kelancaran bahasa kedua.

Tabel 2. Hasil Tes Berbicara Bahasa Jawa

\begin{tabular}{|c|c|c|c|c|c|c|}
\hline No & Kode & JK & Usia & KB & Pg & PK \\
\hline 1 & Eg/11/MM & Pr & 16 & 78 & 73 & 75 \\
\hline 2 & Ib/12/MM & Lk & 17 & 86 & 85 & 83 \\
\hline 3 & Rs/12/MM & Pr & 17 & 90 & 88 & 85 \\
\hline 4 & Rv/11/MM & Lk & 16 & 85 & 88 & 85 \\
\hline 5 & Sy/12/MM & Pr & 17 & 95 & 96 & 90 \\
\hline
\end{tabular}

Keterangan:

$\mathrm{JK}=$ jenis kelamin

Pr = perempuan

$\mathrm{Lk}=$ laki-laki

$\mathrm{KB}=$ kelancaran berbahasa 
$\mathrm{PK}=$ pelafalan kata

Pg = penggunaan kata

Dari tabel di atas dapat diketahui bahwa gender atau jenis kelamin mempengaruhi pemerolehan bahasa. Siswa (1) diketahui berjenis kelamin perempuan tetapi memiliki nilai yang rendah hal ini dipengaruhi oleh kepribadian juga. Siswa (1) diketahui memiliki sifat yang introvert dan jarang sekali berinteraksi dengan teman. Bahkan siswa (1) saat disuruh untuk berbicara, hanya berbicara sesuai dengan apa yang disuruh. Dapat terlihat pada saat Eg/11/MM mulai praktek berbicara bahasa Jawa, banyak pengucapan, penggunaan kata yang tidak tepat.

Eg/11/MM terlihat kesulitan saat mulai berbicara menggunakan bahasa Jawa. Ia tidak tahu pengucapan kata dan penggunaan kata yang benar. Karena memang tulisan dengan pengucapan dalam bahasa Jawa ada yang berbeda. Misalnya seperti kalimat berikut “...tukua sega goreng neng etan kono.” Eg/11/MM akan mengucapkan sesuai dengan tulisannya, tidak memperhatikan ' $a$ ' jejeg dan ' $a$ ' miring semua dianggap sama. Hal ini disebabkan dari kurangnya interaksi Eg/11/MM dengan orang lain. Sehingga membatasi ruang untuk berbahasa yang lebih baik.

Sangat berbeda dengan Eg/11/MM, empat siswa lain jauh lebih baik nilainya. Dapat dilihat siswa (2) dan siswa (4) berjenis kelamin laki-laki, mereka memiliki skor lebih rendah dari pada siswa (3) dan (5). Siswa (2) dan (4) dalam tabel tersebut diketahui nilai yang paling rendah pada pelafalan kata atau pengucapat kata. Dalam pengucapan kata dua siswa laki-laki ini memiliki nilai yang rendah dibandingkan kriteria nilai yang lain. Penyebab rendahnya nilai pengucapan kata dipengaruhi oleh faktor kepribadian yang lain, seperti emosional.

Siswa (3) dan (5) memiliki nilai yang sempurna. Dari ketiga kategori penilaian semua menunjukan hasil yang maksimal. Dari penilain tersebut membuktikan bahwa siswa perempuan lebih baik dalam hal berbahasa daripada laki-laki. Walau ada nilai yang sama antara siswa laki-laki dan perempuan, hal tersebut dipengaruhi juga oleh lama mereka tinggal di Jawa (Surabaya). Seperti Rs/12/MM dan Rv/11/MM, sama-sama memiliki niali 88 pada kategori penggunaan kata yang benar. Diketahui bahwa Rv/11/MM jauh lebih lama tinggal di Surabaya daripada Rs/12/MM. Ini yang menyebabkan adanya persamaan nilai.

Beda lagi dengan Ib/12/MM jika dibandingkan dengan Rs/12/MM. Mereka sama-sama masih baru tinggal di Surabaya, tetapi hasil penilaian menunjukan bahwa Rs/12/MM lebih baik dalam berbahasa Jawa. Pada posisi ini Rs/12/MM masih dua tahun tinggal di Surabaya, sedangkan Ib/12/MM lebih lama satu tahun daripada Rs/12/MM.

Selain penilaian kelancara berbahasa, penelitian ini juga menghasilkan beberapa pemerolehan bahasa yang berbeda antara laki-laki dan perempuan. Perbedaan ini dilihat dari sudut pandang ekspresi emosionalnya. Dari ekspresi emosional laki-laki cenderung 
berbicara lebih kasar dari pada perempuan. Misalnya saat dihadapkan pada situasi yang menjengkelkan siswa laki-laki cenderung mengucapkan kata-kata kasar khas Surabaya. Berbeda jauh dengan perempuan, sama-sama dihadapkan pada situasi yang sulit perempuan lebih menggunakan bahasa yang lembut.

Untuk membuktikan pernyataan tersebut peneliti melakukan pengamatan dengan menggunakan catatan harian. Hasilnya berupa kalimat kasar yang dituturkan penelajar laki-laki, tetapi kalimat tersebut tidak tuturkan oleh siswa perempuan. Hasil tersebut dilihat pada saat sampel sama-sama bermain game dan diganggu oleh teman dekatnya. Siswa laki-laki melontarkan kata sebagai berikut.

(1) "Dhuhh, asu koen ya. Wis meh menang iki." (Duh, sialan kamu. Sudah hampir menang ini.)

(2) "Dhuh ya apa seh, aja nyalah lho."

(Duh, gimana sih, jangan menganggu.)

Pada data (1) siswa laki-laki khususnya Ib/12/MM yang senang berinteraksi dengan teman-temenya memperoleh bahasa kasar asli Surabaya. Dapat dilihat dari kata 'asu', kata ini adalah kata-kata khas orang Jawa timuran. Laki-laki yang memiliki sifat lebih terus terang, mampu menuturkan bahasa-bahasa kasar yang mereka peroleh.

Sangat berbeda dengan data (2) penuturnya merupakan siswa perempuan. Siswa perempuan tidak berkata kasar walau diganggu oleh temannya saat bermain game. Terlihat dari kalimat yang dituturkan pada data (2), kalimatnya lebih halus. Dari kedua data tersebut dapat disimpulkan bahwa perbedaan emosional pada lakilaki dan perempuan memang berbeda jauh.

Diketahui juga bahwa kompetensi perempuan jauh lebih baik dibandingkan laki-laki. Dari segi kemampuan verbal, dijelaskan bahwa perempuan lebih baik dalam berbagai tugas-tugas verbal sejak awal perkembangannya, dan menjadi superioritasnya yang terpelihara, sedangkan laki-laki memiliki lebih banyak masalah berbahasa daripada perempuan. Namun, demikian laki-laki lebih baik dalam tugas-tugas visual. Perbedaan gender dianggap sebagai salah satu determinan yang dapat mempengaruhi prestasi belajar. Selain kelancaran berbahasa, pemerolehnya juga menjadi sorotan peneliti. Pemerolehan bahasa antara pebelajar laki-laki dan perempuan juga menunjukan perbedaan. Hal tersebut dipengaruhi faktor emosioal dan intelektual. Faktor emosional merupakan faktor

\section{Identifikasi Tipe Kepribadian}

Bagian ini akan membahas hasil tes kepribadian pada pebelajar yang diteliti. Tes tersebut menunjukan adanya kepribadian ektrovert dan introvert. Dalam penelitian ini menunjukan bahwa orang ekstrovert tidak selalu bermulut besar dan suka bicara. Ada juga orang ekstrovert yang pendiam tetapi masih membutuhkan bantuan orang lain. Sedangkan introvert bersifat, non-sosial, dan merasa bisa memenuhi kebutuhannya tanpa refleksi dari orang lain. Di 
lingkungan kelas, orang-orang introvert merujuk pekerjaan individual dan aktivitas tertulis.

Penentuan kepribadian sebagian besar diambil dari hasil tes angket kepribadian, selebihnya diambil dari pengamatan langsung dan catatan harian. Dikarenakan yang bersifat introvert hanya satu siswa jadi lebih mudah untuk mengamati. Sedangkan penliaian berbicara ini menggunakan pedoman tes pengamatan berbicara. Hal ini dilakukan untuk mengetahui seberapa berhasil mereka menguasai bahasa keduanya.

Tabel 3. Hasil Tes Kepribadian

\begin{tabular}{|c|c|c|c|c|c|}
\hline No & Kode & JK & Usia & Ektv & Intv \\
\hline 1 & Eg/11/MM & Pr & 16 & - & $\sqrt{ }$ \\
\hline 2 & Ib/12/MM & Lk & 17 & $\sqrt{ }$ & - \\
\hline 3 & Rs/12/MM & Pr & 17 & $\sqrt{ }$ & - \\
\hline 4 & Rv/11/MM & Lk & 16 & $\sqrt{ }$ & - \\
\hline 5 & Sy/12/AK & Pr & 17 & $\sqrt{ }$ & - \\
\hline
\end{tabular}

Keterangan:

$\mathrm{JK}=$ jenis kelamin

Pr = perempuan

Lk = laki-laki

Ektv $=$ ekstrovert

Intv = introvert

Dari tabel 3, dapat dilihat jumlah siswa yang bekepribadian introvert dan ektrovert. Dari tabel tersebut siswa (1) satu-satunya siswa yang memiliki kepribadian introvert, sedangkan untuk yang lain ektrovert. Sifatnya yang tertutup dan mudah sekali merasa malu menyebabkan Eg/11/MM sulit untuk berkomunikasi. Inilah yang menyebabkan Eg/11/MM sulit untuk memperoleh bahasa keduanya.

Eg/11/MM hanya diam saja saat teman-temanya mulai cerewet di kelas, ia hanya mendengarkan saat teman-temannya berbicara. Tetapi proses berbahasa tidak bisa dilakukan dengan hanya mengamati saja, melainkan harus terlibat dalam percakapan. Dari hasil pengamatan siswa yang memiliki kepribadian introvert ini sulit untuk menerima bahasa yang baru.

Seseorang yang memiliki kepribadian introvert cenderung sulit untuk berinteraksi dengan yang lain. Selain itu orang introvert cenderung berfikir tidak membutuhkan bantuan orang lain. Tentunya hal ini sangat berpengaruh pada proses pemerolehan bahasanya.

Berbeda dengan siswa yang berkepribadian introvert, siswa ektrovert lebih mudah berinteraksi dengan orang lain. Selain itu orang berkepribadian ektrovert selalu merasa membutuhkan bantuan orang lain. Tetapi orang ektrovert bukan berarti semuanya banyak bicara, ada juga orang introvert yang sedikit berbicara tetapi masih membutuhkan bantuan orang lain. Rv/11/MM termasuk siswa berkepribadian ektrovert yang tidak banyak bicara. Tetapi 
Rv/11/MM masih mampu berinteraksi baik dengan temantemannya. Rv/11/MM juga menunjukan hasil yang baik pada tes kelancaran berbahasa.

Tipe kepribadian ini tentunya sangat membantu proses pemerolehan bahasanya. Siswa yang memiliki kepribadian ini cenderung mudah menerima sesuatu yang baru termasuk bahasa. Sedangkan orang yang berkepribadian introvert lebih sulit untuk belajar bahasa, karena bahasa harus disertai dengan interaksi dan komunikasi yang baik dengan lawan tuturnya.

SIMPULAN

Dari pembahasan di atas dapat disimpulkan bahwa proses pemerolehan bahasa kedua sangat dipengaruhi oleh jenis kelamin (gender) dan tipe kepribadian yang berbeda-beda. Dari hasil pengmatan dapat membuktikan bahwa (1) terdapat perbedaan pada proses pemerolehan bahasa kedua atara siswa perempuan dan lakilaki, siswa perempuan memiliki kemauan dan kemampuan yang lebih tinggi daripada siswa laki-laki, (2) terdapat perbedaan penguasaan pemerolehan bahasa pada siswa berkepribadian ekstrovert dan introvert, siswa ektrovert memiliki kompetensi pemerolehan lebih tinggi daripada siswa berkepribadian introvert.

Penelitian ini perlu ditindak lanjuti, karena penelitian ini hanya mendeskripsikan faktor internal yang mempengaruhi pemerolehan bahasa kedua. penelitian ini belum mendeskripsikan semua bagian dari faktor internal pebelajar bahasa. Masih banyak tipe kepribadian yang belum diteliti. Begitu juga faktor ekternal dari setiap individu juga perlu diteliti.

\section{DAFTAR PUSTAKA}

Adipitoyo, Sugeng. 2012. Valensi Ratminingsih, Ni Made. 2013. Sintaksis Bahasa Jawa. Surabaya: Citra Wacana.

Ardiana, Leo dan Syamsul Sodiq. 2008. Psikolinguistik. Universitas terbuka: Jakarta. "Pengaruh Gender dan Kepribadian Terhadap Kompetensi Berbicara Bahasa Inggris". Jurnal Pendidikan dan Pengajaran, Jilid 46, Nomor 3, Oktober 2013.

Pristyasiwi, Paundra. 2017. "Penerapan Teori Produksi Ujaran dalam Peningkatan Keterampilan Berbicara Bahasa Jawa Krama”. Dalam Gerenik Linguistika Terapan. Tim Penyusun Mahasiswa Pascasarjana Unesa 2016 B. Surabaya: Meja Tamu.

Yulianto, Bambang. 2011. Pengantar Teori Belajar Bahasa. Surabaya: Unesa University Press. 